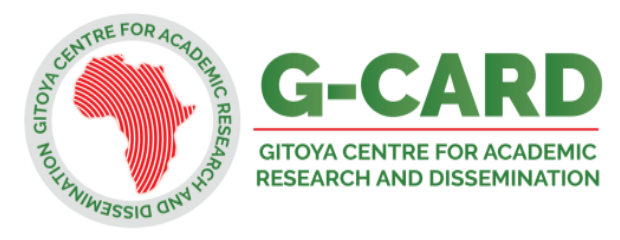

East African Journal of Education and Social Sciences

EAJESS October - December 2021, Vol. 2, No. 4, pp. 1-8

ISSN: 2714-2132 (Online), 2714-2183 (Print), Copyright (C) The Author(s)

Published by G-Card

DOI: https://doi.org/10.46606/eajess2021v02i04.0121

URL: http://eajess.ac.tz

\title{
Analysis and Discussion Concerning Death
}

\author{
Joshua Juma Mugane \\ University of Iringa, Tanzania
}

Corresponding Mail: joshuamugane6@gmail.com

\begin{abstract}
The analysis and discussion concerning death as intended by the Researcher depicts that death is an irreversible condition or state encountered by beings (all living creatures), due to a total dysfunction of the body organs. Such an irreversible condition is an enemy of human beings, which supersedes humanity, causing unexpected changes in life. It came as a punishment of abusing the supernatural power and finally it became a fact of not living forever. By the use of different literatures, Interviews and Documents, the research explored diverse concerns of death and drew its conclusion. Some of those concerns are "how is death detected? What are the causatives of death? Does death have its remedy? Where are dead people? Why do we bury the dead? And what is next after death?" The findings reveal that Doctors prove death by assessing and measuring the vital signs such as Blood Pressure, Pulse Rate, Respiratory Rate and Body Temperature. Moreover, the causatives of death include chronic pulmonary obstructive disease, ischemia, stroke, dehydration, infections and pain as well as old age. Those who encounter death are laid in the graves because God commanded it to be so and they produce unpleasant smell and stink. The remedy of it depends on the supernatural power that is believed to have ability of restoring the lost lives at consummation. That's why Christians believe that on the second coming of Jesus Christ, all the dead shall rise. Hence, human beings have to be kin enough in lifetime, so that they may prolong a bit their lifespan through observance of health principles and guidelines.
\end{abstract}

Keywords: Death, Perspective, Vital Signs, Causatives, and Function Failure of the Body

\section{Introduction}

Death is one of the difficult scenarios to explain, teach, clarify and define. From ages, people have been startled by the fact of death within their lives. Such a startling state limits their brains and senses to clearly spell out what death is. Scientists;Biologists and health specialists, have tried to illuminate the concept of death, but still there is a gap. Theologians have tried to exegetically analyse the concept but still there is a gap. Yet, Pastors, preachers and Bible readers have tried to illuminate it but still there is inconsistency. Finally, whoever was or is bereaved may try to illuminate people concerning death, but still there is no common answer. Then if so, what is death? Under which condition is a dead person? How is death like? This paper sought to analyse and discuss the topic. The discussion touches key concepts of death; meaning, state or condition and effects.

\section{The General Perspective Concerning Death}

In a general sense, no any human being is a friend of death. Even those who try to commit suicide are not lovers of death, but they do so as a way of escaping realities in lifetime. Then if so, death is always an enemy of human beings. Green (2004) says, "Death is unwelcome fact at the end of the road." Such thinking may be seen unto the houses of the bereaved, specifically during weeping and wailing for their brethren who have died. In such a state, death is seen as a tragedy that supersedes humanity, causing unexpected changes in life. Then if that is the case, death acts as a power which separates people living in space and time.

Such a situation reminds us of a definition of death: "Death is separation from the loved ones" (Welwel, 2020). The concept is very relevant to what we see happening in life. Those who are proven to be dead have no more chance of mingling or staying with their brethren; and are directly taken to the

1 East African Journal of Education and Social Sciences (EAJESS) 2(4)1-8 
mortuaries as "cargoes with no value, waiting to be buried." Then if so, such a situation proves that death is a separation from lovers. Moreover, death is considered as a point of no return-as people may believe that once gone out of time and space, there will be no point of returning again as a human being in the same time and space. Therefore, due to such a situation, people cry, weep, mourn and wail for such a loss of their brethren.

\section{Biblical and Theological Perspective of Death}

Theology-which is a sub branch of Philosophy, under Metaphysics, agrees with the Bible on the terms of defining death as a punishment for sinning. Worancha (2014) says "the clear message of the Bible is the wages of sin is death. Such a death was to be eternal, as proclaimed by God, when He was forbidding Adam and Eve to eat the fruit of the tree of knowledge of good and evil." Then if so, is it true that death came because of eating the forbidden fruit? Mugerwa (2014) argues that eating the forbidden fruit was the outward expression of the inward situation. Thus, due to that fact, eating the forbidden fruit can't only be a factor which caused God to punish humanity by allowing death. In the mind of Mugerwa, death is the product of an objective cosmic power which dominated as the result of Adam and Eve's distrust in God. Their distrust was on what God said against what the serpent said later unto them. As Genesis 2:16-17 records of God's directives, Genesis 3 records of the serpent's criticism of the directives from God-God knows that in the day you eat of it [tree of Knowledge of good and evil] your eyes shall be opened, and ye shall be like God, knowing good and evil (Genesis 3:5). Then such serpent's expression to humanity influenced their conscience to desire being like God and knowing good and evil. And due to such a fact, they distrusted God by eating the fruit of the forbidden tree, as a demonstration of accepting the serpent's statement. Hence, due to such a scenario, God punished them by fulfilling His statement "if you eat, you will surely die."

If death is the product of an objective cosmic power which dominated as the result of Adam and Eve's distrust, that power has to weaken human's nature. And that weakening results into changes from conditional immortality (being in God's image and likeness-Genesis 1:26-27) towards mortality. Then as the way the word "mortality" refers to "the fact that nobody can live forever (Wehmeier, 1993), death is all about mortality-a proof of not living forever.

\section{Psychological Perspective of Death}

In Psychological grounds, Psychologists have their attitudes towards death. According to Psychological awareness of death, death is a daily and natural event which affects those living as part of nature. When a person encounters its naturalness, mortality-a proof of not living forever becomes inevitable (Moor, 2002). Moreover, Psychologists agree that we cannot truly understand our own mortality, though it continues to be influential. And since we "know" that we cannot know death (Freud, 1956), lets understand that the mysterious character of death and the sufferings that normally precede it, have strongly touched people of all times (Bautista, Escobar \& Miranda, 2018).

\section{Medical Perspective of Death}

Under medical perspective, doctors, nurses, biologists and scientists believe that "death occurs when the fundamental functions of the body; cardiac activity and respiratory activity cease. And such a cessation of fundamental functions of the body is what is referred to as death" (Montiel, 2003). For Biologists, death happens when the brain has completely and irrevocably ceased to functionit is known as central death, when finally the whole body organs cease to function-it is known as total death. They believe that central death happens when there is (1) Complete and permanent absence of conscience; (2) Permanent absence of spontaneous breathing; (3) Absence of brainstem reflexes, manifested by pupilar areflexia; (4) absence of ocular movements in vestibular tests; and (5) absence of response to nociceptive stimuli (Küng, 1997).

\section{Research Methodology}

With reference to the topic under study, the Explorative Research Design was used. It was used because it is applicable to what is unknown; to something one is not sure of, so as to acquire the detailed information (Gimbi, 2012). Nkoko (2017) explains it as one of a Research design which is helpful to the researcher, especially when he/she has a spirit of learning; and it helps him/her to attain flexibility and success in acquiring the needed information. The Review of Documents and Interviews were used as Data Collection Methods. Interviews were applied because they usually enable the respondents to speak for themselves (Sherman \& Webb, 1988), specifically on what they perceive and know. The Review of the Documents consisted of Journal articles, books and Researches reports. 
The participants of this study included two doctors from Mafinga Hospital, Iringa-Tanzania and a graduates of Doctor of Medicine (MD) from Kampala International University-Tanzania, two professors of Theology from Bugema University and ten students from Bugema University. Through comprehensive interviews with the researcher, the mentioned participants openly, clearly and thoroughly shared their knowledge, understanding, perceptions and experience concerning death. They demonstrated to the best of their knowledge the reality of death, as a factor that encounters every living creature without hesitating to identify its causes, its signs and symptoms, its state, and its effects.

\section{Results and Discussion}

From the interviews done, the respondents failed to give out a common definition of death. Instead, they explained it on the basis of causatives, scientific measurements, signs, symptoms and observable attributes. Moreover, they agreed that death happens when fundamental functions of the body ceases as indicated below.

\section{How is Death Detected?}

According to the interviewed Doctor from Mafinga Hospital, Iringa-Tanzania, "death is detected after an assessment, measurement and evaluation of vital signs within the body of a living organism. Such vital signs include (1) Blood Pressure, (2) Pulse Rate, (3) Respiratory Rate, (4) Body Temperature." Her belief and experience as a Doctor is that "When a living organism shows abnormality on vital signs, death is inevitable. And when a test is done to a person with the results of zero, that person is dead-Blood Pressure (0), Pulse Rate (0), Respiratory Rate (0), and Body Temperature below $36.5{ }^{\circ} \mathrm{C}$. By such facts, those who prove that a certain living body has encountered death-doctors, nurses, surgeons, etc., search for a cluster of signs rather than a single infallible sign-for the diagnosis of death (Alexander, 1980).

If vital signs prove to us that a living body has encountered death, possibly the function failure of vital organs; heart, brain, liver, kidneys and lungs prompts what is known as death. Then if so, the functioning of many organs-such as the liver, kidneys, etc., is "vital" to individual's health. In case anyone ceases and that function is not restored or artificially re-placed, the organism as a whole cannot long survive. Thus, all elements in the system of human body are mutually interdependent. And the loss of any part leads to the breakdown of the whole body, and eventually, leads to the cessation of functions in every part-a fact of death (Grisez, \& Boyle, 1979).

\section{The Causatives of Death}

Death is determined by many health and physiological factors, which may be merely stated as the causatives of death. Thus, the following are some of the key factors that seem to be common to whoever will encounter death:
1. Chronic Obstructive Pulmonary Diseases
2. Ischemia
3. Stroke
4. Dehydration
5. Infections and Pain
6. Old age

Such factors are simply stated as common catalysts for death. And whoever encounters them is likely to encounter death. Then if so, let us pass across each factor, so that we may clearly understand them.

\section{Chronic Obstructive Pulmonary Diseases}

Under this common factor, doctors usually evaluate the breathing rate of a living organism. When they notice a severe failure of breathing rate within the living body, it is thus called "Chronic Obstructive Pulmonary Diseases." They are under a group of chronic diseases affecting the airways and the other structures of the lungs. Such diseases include Asthma, Bronchiectasis, Chronic rhinosinusitis, Hypersensitivity pneumonitis, etc., (WHO, 2018). When such breathing complications emerge, a person may easily face a total failure to breathe in and out. And due to that total failure, death is likely to occur.

The conformation of such a death is prompted by the failure of lungs with its components to function. As it is known, the lungs are made up of more than 300 million tiny air sacs called alveoli; these air sacs are normally stretchy and springy. When you breathe in, the airs sacs expand like tiny balloons; and breathing out usually is passive (takes no effort) as the alveoli "spring" back to their original size. Thus, inflammation and swelling happens within the lungs cause the inside of the breathing tubes (airways) to be smaller than normal; and this narrowing interferes with how well and how easily air empties out of the lungs-expiration (Lareau, Fahy, Meek \&Wang, 2019). Then due to such a condition, the lungs may not function properly; leading the body to have no oxygen transformation and circulation. Hence, a living body becomes 
Oxygen-less; and that state of Oxygen-less attained by a living organism is what is known as death.

\section{Ischemia}

Doctors and scientists explain and clarify the word "Ischemia" as a heart disease, which is determined by an imbalance of myocardial energy state and coronary blood flow (Severino, 2020). Due to such a fact, the interviewed Doctor from Mafinga Hospital puts it clear that: "Ischemia is all about the insufficient supply of the blood from the heart to the rest parts of the body." And as it is known and believed that the heart is associated with issues of blood, failure of it to foster the pumping of the blood prompts Ischemia. Thus, under such a case, death is inevitable because of insufficient blood supply from the heart to the rest parts of the body.

Blood supply is of more importance in the life of a living organism. As it is clear that blood (1) supplies oxygen to tissues; (2) supplies nutrients such as glucose, amino acids and fats; (3) removes wastes such Carbon dioxide, urea and lactic acid; and (4) support immunological functions like circulation of Red Blood Cells, and detection of foreign materials by antibodies (Moss, 2017), its insufficiency interferes the normal functioning of the body. And when there will be interferences, human body parts won't function. Hence death happens as a state in which the body with its organs does not function.

\section{Stroke}

This is also one of the causatives of death. In a simple way, one may define it as: "abrupt onset of a focal neurological deficit or cerebrovascular accident (CVA) or apoplexy (Easton, Hauser \& Martin, 2001). The interviewed Doctors explained it as "a body disorder which is accompanied by the clotting of blood or fats." And in most cases, it is resulted from sudden decrease of blood flow to the brain which causes rapid loss of body functions (Wittenauer \& Smith, 2012). Then if so, such a rapid loss of body functions prompts what we may refer to as death.

\section{Dehydration}

In most cases, people die due to lack of water within their bodies. And that condition of lacking water within the body is known as "dehydration" (Mange, Matsuura \& Cizman, 1997). Dehydration happens when several processes are undergone by the body. Such processes include (1) sweating, (2) breathing, (3) urinating, and (4) speaking (Mtango, 2021). As the way water is very important within the body of organism, its low concentration interrupts its normal functioning. According to Lieberman (2007), dehydration results into loss of body weight by $1 \%$ to $5 \%$ and it prompts dysfunction of the Central Nervous system. Moreover, dehydration prompts (1) constipation-which may later lead to Colon Cancer, (2) irregular blood pressure control, and (3) uncontrolled body temperature. Thus, due to such failures, a living body may cease to cope with all irregularities. Hence, it may collapse other body functions and finally death (a state attained due to the failure of body organs, with its functions) may be encountered.

\section{Infections and Pain}

According to statistics of mortality rate, a lot of deaths occurring in this world are due to infections and pain accompanied by shock. According to loannidis (2020), the infection fatality rate is not fixed, physical or constant. It can vary substantially across locations, depending on the population structure, the case-mix of infected and deceased individuals and other, local factors. Under infections, there are several modes which prompt diseases. For example, there are sexually transmitted infections (STIs)-which prompt gonorrhea, syphilis, chlamydia and trichomonas (Rowley et al., 2019). Moreover, infections affect what is known as immune system. And because the immune system is a network of cells, tissues and organs that work together to defend the body against attacks by "foreign" invaders such as bacteria, viruses, parasites and fungi, it is the immune system's job to keep them out, failing their efficiency and to destroy them all (U.S. Department of Health and Human Services,2003). The failure to do so, immune system becomes weakened. And when it is weakened, the body functions may stop and finally death (a state attained due to the failure of body functions).

Furthermore, the pain resulted from the diseases prompted by infections foster death. According to Drummond (2003), "pain leads the unexpected deaths. Pain is associated with Coronary spasm or Cardiac arrhythmia, leading to Cardiac arrest, horrific stress (Lewis, Whipple, Michael \& Quebbeman 1994), and abnormal rise of both pulse rate (100 to 130 beats per minute) and Blood pressure-which may reach more than $200 \mathrm{mmHg}$ systolic (Nakagawa \& Hosokawa, 1994). Then if so, such effects due to pain interrupt different or several functions of the body. Hence, when the body fails to function itself death (a state attained 
due to the failure of body functions) may be encountered.

\section{Old age}

According to Malekana (2021), old age is the causative of death. He argues his point depending on the context of Genesis 25:8 when Abraham died in a good old age and full of years. To him, death seems to be a final condition of a weak humanity, which is accompanied by the function failure of the whole body-with its organs. Then if so, old age is a catalyst which prompts the function failure of the whole body, with its organs. Hence, old age seems to be one of the causatives of death (a state attained due to the failure of body organs, with its functions).

\section{Does Death Have Its Remedy?}

Talking about the remedy of death is very critical. If we have to think of the remedy of death, we have also to think about the power which will conquer death. Looking back at the venue of our genesis, history doesn't abandon the fact of death. If humanity existed due to the presence of a supernatural power then probably, death comes after an abuse of both supernatural and natural powers. The interviewed graduate of Doctor of Medicine (MD) at Kampala International University-Tanzania puts it clear by saying: "all what we see and experience today is a result of abusing the nature with its civilizations." In case humanity abused the supernatural power with its civilization, humanity can't save itself from death. Then if so, it needs supernatural power to rescue humanity from death. Thus, an act of rescuing humanity from death is what may be referred to as "The Remedy of Death".

\section{Where are the Dead?}

A question to think about is: "if the dead live somewhere while doing something, why do the bereaved cry for the dead?" Possibly the dead have no any special place to go, and nothing they can do after death. The Archaeologists through their excavation prove this fact by recording human remains, which may be found in the soil. For instance in England and Italy, biological materials of human remains were discovered (Rajala, 2016). Likewise, the research conducted at Olduvai Gorge (a place where the skull of a human being was discovered by Dr. Leakey) shows that even the remains of living things such as birds and trees were discovered to exist in the soil (Eren, Duran, Prendergas \& Mabulla, 2014). Such a proof postulates that the dead have no a better place to go, rather than to the soil. Moreover, the Bible proves such an idea by saying: "the dead came out of the grave; the dead in the grave (Mathew 27:53; John 5:28). Thus by such an expression, all the dead are laying in their graves; and they have gone no anywhere, because even death which is a state attained due to the failure of body organs with its functions, proves to us that men can't be able to do anything (even moving by walking) after dying. Hence, all the dead are laying in the graves or soil.

\section{Why Do We Burry the Dead?}

In our communities, dead people are buried every day. But why do we burry them? The Respondents of this study recalled the statement of God that is believed to bring death in the world. And by referring to Genesis 3:19, they openly said: "The dead people are buried because God commanded it to be so." They continued to say that: "the dead are buried because they stink and produce unpleasant smell." That's why even Lazarus (a relative of Martha and Mary Magdalene) was buried because he started to stink (John 11:39).

\section{What is next after Death?}

In African Traditional Religion, death stands between the world of the living (human beings) and the world of the spirits or between the visible and the invisible world. With such thinking, the Africans value this world like a voyage and they believe that everyone will go home one day. Then if so, death is an event that returns everyone back home. Hence, they do not see death as the end of life, because it is seen as a transition from the present earthly life to another life in the land of the spirits (Lateju \& Inyang, 2008).

Such thinking postulates an idea that: "there is a hope beyond death." On different basis or grounds such as theology, religious, philosophical and rational, there may be life after death. For Theology, death will be destroyed at consummation-the second coming of Jesus Christ. "Christ promises his followers eternal life while threatening those who turn away from him with eternal punishment." For example, such a fact is portrayed by Apostle Paul, in his letters: "For Christ himself will descend from heaven with a cry of command, with the arc angel's call, and with the sound of trumpet of God. And the dead in Christ will raise first" -1 Thessalonians 4:16, RSV. Hanson and Blaney (1955) put that statement clear by saying: "an act of the dead in Christ to be raise first is all about the resurrection of the righteous, which will take place in Christ's second 
coming." And such a resurrection is all about "the restoration of life; together with fullness of being and personality subsequent to death" (Horn, 1960). Then if so, "He that believeth in me (Jesus), though dies, shall he live"-(John 11:25). Therefore, as the word "Believing" refers to a state of thinking something to be true and finally having confidence on it, those who have such a criteria are assured of Jesus' promise concerning resurrection-life after death.

For Philosophers and Rationalists, there are divergent views and arguments pertaining life after death. But amidst all views, none has drawn a conclusion statement as to whether there will be life after death. Although in records Plato affirmed both pre-natal life of the soul and the soul's continued life after death and Socrates proposed reasons as to why even a philosopher should welcome death, such philosophical assessment of the truth concerning death continues on to the present. And its implication of whether we may survive after death or not is still on the debate (Hasker, 2019). Moreover, because the rationality is all about using the past to make predictions about the future (Zerner, 2014), rationalists have failed to draw a conclusive statement, because there has been no any proof of forever living after death-even those resurrected by Jesus like Lazarus (John 11:1-44) died again. Then if so, Theology might be the best reference concerning life after death.

\section{Conclusions and Recommendations}

Within living organisms there is unknown ability in which they were created. The clarification of such unknown ability is not very clear. When such ability becomes triggered, human body with its organs and systems fail to function; that's why even when you put a man under Intensive Care Unit (ICU) and Oxygen, still a person may encounter death. Then if that is the case, Death is an irreversible condition or state encountered by beings (all living creatures) due to a total dysfunction of the body organs. It encounters humanity as a fact of not living foreverthis is all about mortality. It happens because of God's statement after human beings sinned; and the physiological disorders in a living organism. It isolates no one because it deals with nature, and not status. It is not escaped by any means or efforts. For sure, death is a power that supersedes human nature; and what is more important is that human beings must accept the real condition of death, especially when it resides on their path.
Moreover, those who happen to die, they will be laid in the graves; and its where their remains may be found because God commanded it to be so (Genesis 3:19). The hope after death is there as Christians believe that on the second coming of Jesus Christ, all the dead shall rise; and African Tradition Religionists believes that death acts as a passage taking people in the land of ancestors, thus it is not the end of life. Hence, human beings have to be kin enough in lifetime so that they may prolong a bit their lifespan-through observance of health principles and guidelines.

\section{References}

Alexander, Marc. (1980). "The Rigid Embrace of the Narrow House: Premature Burial and the Signs of Death," $10^{\text {th }}$ Hastings Control Report. (25), 30-40.

Bautista, Jesús Silva., Escobar, Venazir Herrera and Miranda, Rodolfo Corona (2018). Psychological Study on the Origin of Life, Death and Life after Death: Differences between Beliefs According to Age and Schooling. Universal Journal ofEducational Research (6), 1175-1186.

Drummond, P.D. (2003). The effect of pain on changes in heart rate during the Valsalva Manoevure. Clin Auton Res; (3), 316-320.

Easton J.D, Hauser S and Martin J. (2001). Harrison's Principles of Internal Medicine: Cerebrovascular diseases. New York: McGraw-Hill Publisher.

Eren, M. I., Duran A. J., Prendergast M., Mabulla A. Z. P. (2014). Middle Stone Age Archaeology at Olduvai Gorge, Tanzania. Quaternary International 2(1), 292-313.

Freud, S. (1956). "Our Attitude Towards Death." Collected Papers, Vol. 4, London: Hogarth.

Gimbi, A. (2012). Research Design in the Open University of Tanzania: Research Methodology. Darban: Excel Learning Pty. Ltd.

Green, Michael. (2004). The Corinthian Agenda. Lottbridge Drove, EN: Kingsway Communication Ltd.

Grisez, Germain \& Boyle, Joseph M. (1979). Life and Death with Liberty and Justice: A Contribution to the Euthanasia Debate. 
Notre Dame: University of Notre Dame Press.

Hanson, Carl and Blaney, Harvey J. S. (1955). Exploring the New Testament. Kansas City, MO: Beacon Hill Press.

Hasker William. (2019). Stanford Encyclopedia of Philosophy: Afterlife. Retrieved from https//:www.plato.stanford.edu on $13^{\text {th }}$ June, 2021.

Horn, Siegfried H. (1960). Seventh-Day Adventist Bible Dictionary. Rev. Ed. Washington, D.C.: Review and Heralds Publishing Association. 1960.

Ioannidis, John P A. (2020). Infection fatality rate of COVID-19 inferred from $\mathrm{s}$ eroprevalence data. Stanford, CA. Bulletin of the World Health Organization; (1),1-37.

Küng H, Walter J. (1997). Morir con dignidad: Un alegato a favor de la responsabilidad. Madrid: Editorial Trotta.

Lareau, Suzanne C., Fahy, Bonnie., Meek, Paula and Wang, Angela. (2019). Chronic Obstructive Pulmonary Disease (COPD): Patient Education Information Series. American Thoracic Society; (1), 1-2.

Lateju, Fola and Inyang, E. E. (2008). Introduction to African Traditional Religion. Lagos: National Open University of Nigeria.

Lewis K.S, Whipple J.K, Michael K.A, and Quebbeman E.J. Effect of analgesic treatment on the psychological consequences of acute pain. America Journal of Hospital Pharmacy: (2), 1539-1554.

Lieberman H.R. (2007). Hydration and cognition: A critical review and recommendations for future research. J Am Coll Nutr: (26), 555561.

Mange K., Matsuura, D., Cizman, B. (1997) "Language guiding therapy: The case of dehydration versus volume depletion." Ann Int Med: (127), 848-853.

Malekana, Mark Warwa. (2021). Jinsi ya kuahirisha Mazishi yako: Mahubiri ya Shangwe Katika Njia yake-How to Preserve long the days before your Burial: Seminars of
Rejoicing within His Path. Kizota: Hope Chennel Tanzania; (3) 7:20 PM to 8:00 PM.

Montiel J. (2003). El pensamiento de la muerte en Heidegger y Pierre Theilhard de Chardin. Utopía y Praxis Latinoamericana. Revista Internacional de Filosofía Iberoamericana y Teoría Social. (8): 59-72.

Moor, Argo. (2002). Awareness of Death: A controllable Process or a Traumatic Experience? Folklore: Electronic Journal Folklore: (23), 92-114.

Moss, Mathew. (2017). Mathew Moss' Class Notes for Science: Blood Parts and Functions. Chitraoff: MMHS Science; $(1) 1-10$.

Mtango Daniel. (2021). Matumizi Sahihi ya maji kwa ajili ya afya zetu: Mahubiri ya Shangwe Katika Njia yake-The proper use of water for our health: Seminars of Rejoicing within His Path. Kizota: Hope Chennel Tanzania; (3) 6:20 PM to 6: 50 PM.

Mugerwa, Reuben T. (2014). Righteousness of Faith: A Theological Analysis. $2^{\text {nd }}$ Ed. Kampala: Prof. Mugerwa Foundation.

Nakagawa H and Hosokawa R. (1994). Study of the Stress Response to acute pain in the awake human. Pain Clinic; (4), 317-324.

Nkoko, Ntambala Rabson. (2017). Accounting for the 1990-2013 Christian-Muslim Conflicts in Tanzania: A Thesis Submitted in Fulfillment of the Requirements for the Degree Doctor of Philosophy in Religious Studies of the Open University of Tanzania. Dar es Salaam: Open University of Tanzania.

Rajala, U. (2016). Separating the Emotions: Archaeological Mentalities in Central Italian Funerary Archaeology. In: Williams H, Giles $M$ (eds) Archaeologists and the Dead: Mortuary Archaeology in Contemporary Society. Oxford University Press, Oxford.

Rowley J, Vander Hoorn S, Korenromp E, Low N, Unemo M, Abu-Raddad LJ, et al. (2019). Global and Regional Estimates of the Prevalence and Incidence of Four Curable Sexually Transmitted Infections in 2016. World Health Organization Bulletin; (6), 377440. 
Severino, Paolo., Andrea D'Amato., Francesco Fedele., et.al. (2020). Ischemic Heart Disease Pathophysiology Paradigms Overview: From Plaque Activation to Microvascular Dysfunction. International Journal of Molecular Sciences; (21), 1-30.

Sherman, R. R., and Webb, R. B. (1988). Qualitative Research in Education: Focus and Methods. London: Falmar Press.

U.S. Department of Health and Human Services. (2003). Understanding the Immune System How It Works. National Institutes of Health Publications: National Institute of Allergy and Infectious Diseases (3), 1-63.

Wehmeier, Sally. (1993). Oxford wordpower Dictionary. Oxford: Oxford University Press.

Welwel, Michael B. (2020). A Definition of Death from an Intensive Interview at Bugema Univeristy. Milne Hostel.
Wittenauer, Rachel and Smith, Lily (2012). Ischaemic and Haemorrhagic Stroke: Priority Medicines for Europe and the World-"A Public Health Approach to Innovation." Background Paper: (2), 6-46.

Worancha, Gebre. (2014). Life or Death, Your Choice! South Korea: Everlasting Gospel Publishing Association.

World Health Organization (WHO). (2018). Chronic Respiratory Diseases: Chronic Disease Epidemics. Retrieved from https//:www.who.int on $6^{\text {th }}$ June, 2021

Zerner Adam. (2014). What do Rationalists think about the afterlife. Retrieved from https//:www.lesswrong.com on $13^{\text {th }}$ June, 2021 